\title{
Investment Governance to Reverse Unjustified Privileging of Investors
}

\author{
Kinda Mohamadieh ${ }^{1}$
}

Published online: 20 April 2021

(c) Society for International Development 2021

\begin{abstract}
This article discusses approaches to re-envisioning the investment governance regime with a view towards reversing unjustified privileging of investors, including the roles of home and host states in reviewing international investment agreements as well as advancing related national legal frameworks pertaining to investor obligations.
\end{abstract}

Keywords Investment treaties $\cdot$ Arbitration $\cdot$ Development $\cdot$ Rights $\cdot$ Reform

As an international consensus on the Sustainable Development Goals (SDGs) emerged, so did convergence among the international community that reform is needed in the international legal regime governing investors and investments. When the latter is discussed, the focus shifts to international investment agreements (IIAs) and other investment rules in free trade agreements.

A more holistic approach entails consideration of the role of a broader set of rules and norms. ${ }^{1}$ These include, but are not limited to, national investment laws, as well as laws pertaining to labour, tax, corruption, human rights, environmental protections, balance of payments, in addition to terms and conditions set in investment contracts.

This article focuses on issues pertaining to investor rights and obligations under IIAs and their interactions with other sets of norms, particularly human rights law. It argues that, if we are to reimagine the governance regime of investors and investments, the focus should shift from creating an enabling environment for investors and increasing quantities of investments towards creating an enabling environment for progress towards sustainable development objectives, whether those are set nationally or internationally. This requires a shift towards rethinking the interactions between the three core actors in these processes, including states, investors -both national and international-and communities and resources at the heart of national development and sustainability processes. It also requires changes in the roles of both home

Kinda Mohamadieh

kindam@twnetwork.org

1 Third World Network, Geneva, Switzerland and host states of investors and in the ways in which they cooperate.

Historically, developing countries have sought holistic approaches to investment policies, including through their proposals under the project towards a New International Economic Order (Ogle 2014). One of these, a Code of Conduct for Transnational Corporations (TNCs), ${ }^{2}$ was meant to establish a multilateral framework to address the rights and responsibilities of TNCs and Host State governments (Sauvant 2015: note 10). It was a multi-dimensional endeavor. Besides addressing the treatment of TNCs by host countries, it also addressed the observance by investors of domestic laws, regulations and administrative practices as well as the renegotiation of contracts where needed. It also tackled the adherence of TNCs to economic goals and the development objectives of host states, as well as socio-cultural objectives and values, respect for human rights and fundamental freedoms and abstention from corrupt practices. The Code addressed ownership and control, employment conditions and industrial relations, impact on balance of payments and financing, transfer pricing, taxation, competition and restrictive business practices, technology transfer, consumer protection, environmental protection and disclosure of information among other elements central to the conduct of TNCs.

\footnotetext{
${ }^{1}$ Perrone (2020) argues: 'The proliferation of IIAs and ISDS have contributed to narrowing the FDI agenda, removing issues such as control, balance of payments, labour, taxation and information sharing from the discussion', thus 'shift(ing) the attention away from a more holistic approach to FDI. A key policy question is whether this fragmented approach remains consistent with the 2030 Sustainable Development Goals (SDGs)'.

2 https://digitallibrary.un.org/record/159031? In=en Accessed 20 May 2020, http://ccsi.columbia.edu/files/2015/03/KPS-UN-Code-proof-2Journal-of-World-Investment-and-Trade-March-2015.pdf.
} 
Negotiations on the Code did not succeed and it remained a draft document. Failure has been attributed to multiple factors, including the complexity of the negotiations and changes in the underlying political and economic circumstances and interests of developed and developing countries (Sauvant 2015). Yet, the lack of interest, and sometimes objections, by developed countries to establish obligations on their multinational corporations was one of the most influential factors leading to the end of the negotiations.

Today, declarations on the need to reform investment governance regimes in order to align them with sustainable development have proliferated nationally and multilaterally. Yet, there does not seem to be a common direction of travel among the international community when it comes to this reform. Experience of various countries shows divergent approaches (Mohamadieh and Uribe 2016). Multilateral discussions, such as the ones held at UNCTAD on international investment treaty reform and sustainable development ${ }^{3}$ and that held at UNCITRAL regarding reform of investor-state dispute settlement (ISDS) ${ }^{4}$ also show divergent priorities and approaches among Member States. More recently, the call for intensified investment for development has been used at the WTO to argue for and justify new multilateral rules on investment governance (Sauvant 2019; Mohamadieh 2019a). ${ }^{5}$

Broadly, there are two main trends in approaching the 'reform' endeavor. One focuses on reforming with the intention of saving as much as possible of the status quo and relegitimizing the existing governance regime. Another entails a change towards a new vision that reviews the fundamental underpinnings of the system and seeks to re-envision new, more balanced approaches. These processes could entail withdrawal from existing investment agreements, as several developing countries have already done (South Centre 2015). ${ }^{6}$

Thus, it is important to keep in sight the factors that drive the call for 'reform', including the vision and purpose that underpins it, the approaches it adopts, including whose voices are heard and whose interests are accounted for in such processes.

Besides the needed reforms of international rules, rethinking governance regimes pertaining to investors also requires attention to the national level. This includes attention to the place and role of national investors in the larger

\footnotetext{
${ }^{3}$ UNCTAD Reform Package for International Investment Regime, https://investmentpolicy.unctad.org/uploaded-files/document/UNCTAD_Reform_Package_2018.pdf.

${ }^{4}$ https://uncitral.un.org/en/working_groups/3/investor-state.

5 https://www.wto.org/english/thewto_e/minist_e/mc11_e/briefing notes_e/bfinvestfac_e.htm.

${ }^{6}$ https://www.southcentre.int/book-by-the-south-centre-2015-2/.
}

quest to harness and link investment to sustainable development. Moreover, the role of national laws and institutions, including domestic courts, is crucial when regulating the relations between investors and states and between investors and third parties, including the local communities impacted by investor practices.

\section{IIAs: A Regime of Privileges Dedicated to Foreign Investors}

The international governance regime of cross-border investment is primarily comprised of more than 3,200 IIAs, including investment rules in free trade agreements. ${ }^{7}$ It has been well documented that these treaties are fundamentally unbalanced (UNCTAD 2014: ch. VI). ${ }^{8}$ They primarily focus on providing protections to foreign investors and tend to privilege investors for the mere fact that they are foreign and not for any reason connected with the qualitative value added that could potentially be attached to their investments. These treaties usually do not impose obligations on investors.

IIAs provide foreign investors with the legal power to directly sue the state and seek compensation for what is considered adverse acts or omissions by a sovereign state. These could include direct or indirect expropriation or regulatory interventions that are considered to impair or breach certain standard of treatment provided under the treaty, including non-discrimination, the 'fair and equitable treatment' standard, and protection against illegal or uncompensated expropriation (Correa and Vinuales 2016).

The majority of existing investment agreements provide for international arbitration as the mechanism to deal with such disputes between investors and the state, known as investor-state dispute settlements (ISDS); a 2012 OECD survey showed that $96 \%$ of such treaties contained such provisions (Gaukrodger and Gordon 2013). The drafting of these treaties' standards of protection is often indeterminant, enabling international investment arbitration tribunals, which are composed of private arbitrators, to adopt an expansive interpretation that often privileges investors in comparison to the state and its actions taken in the public interest (Van Harten 2018).

Country experiences have demonstrated that such IIAs can have an adverse impact on various policy areas that are generally important in the achievement of their development objectives, including industrial policy goals, tax reform,

\footnotetext{
$\overline{7}$ https://investmentpolicy.unctad.org/international-investment-agree ments.

${ }^{8}$ https://www.southcentre.int/book-by-the-south-centre-2015-2/. http://unctad.org/en/pages/PublicationWebflyer.aspx?publicationid= 981, Singh and Ilge (2016).
} 
the use of capital controls, intellectual property rights, public-private partnerships and climate change action in relation to investment in clean technologies (Mohamadieh 2019b). The investors' right to directly sue host states has allowed unprecedented challenges of governmental action, including non-discriminatory regulations, in many of these listed areas (Johnson 2019). ${ }^{9}$ The way in which investors have been using the ISDS mechanism to bring, or threaten to bring, costly cases against states that are undertaking, or planning to undertake, new legislation and other measures related to sustainable development, could effectuate a 'chilling effect' on the regulatory process.

In the time of the COVID-19 global public health crisis, the biggest emergency health crisis in recent history, the international investment rules could potentially be utilized by big corporations and asset holders to challenge measures that states, both developed and developing, have been taking in response to this crisis (Bernasconi-Osterwalder et al. 2020; Olivet et al. 2020). For example, many governments are finding themselves in a condition that obliges them to take unprecedented measures, such as taking over private corporations to manufacture essential health equipment, closing down non-essential services and restricting local or national movement, taking various measures related to transport of essential goods and workers, taking measures to ease the issuance of compulsory licenses and to access patented drugs and medical equipment, among other measures (Bernasconi-Osterwalder et al. 2020; Olivet et al. 2020). Several of these measures are following on recommendations by the World Health Organization. A civil society report has documented how investment lawyers and law firms have advised their corporate clients on the use of ISDS to challenge such measures (Olivet et al. 2020). ${ }^{10}$

There are already over 1,000 known ISDS cases according to UNCTAD. ${ }^{11}$ Some developing countries have billions of dollars outstanding in pending ISDS claims. For example, a report by civil society groups indicates that in 2020 (as of

\footnotetext{
9 The ISDS mechanism has already been used to challenge state interventions in multiple areas of crucial importance for the public interest such as pricing of domestic tariffs for essential public services, domestic court decisions regarding the appropriate scope and nature of intellectual property rights, efforts to combat aggressive tax avoidance, efforts to scale back grants of wasteful and unwise incentives, policy approaches aiming to help ensure host countries and communities receive some of the potential benefits of FDI, decisions regarding environmental permits, and measures to tackle climate change.

10 This points out that 'On 26 March 2020, international arbitration law firm Aceris told its clients that "while the future remains uncertain, the response to the COVID-19 pandemic is likely to violate various protections provided in bilateral investment treaties ("BITs") and may bring rise to claims in the future by foreign investors",

11 https://investmentpolicy.unctad.org/investment-dispute-settlement.
}

the time of writing), Mexico has 12 pending cases, making up a total of US\$ 5.4 billion in claims, while India has 13 pending cases amounting to US\$ 8 billion in claims (Olivet et al. 2020). This calculates that by the end of 2018, states worldwide had been ordered or agreed to pay investors in publicly known ISDS cases the amount of US $\$ 88$ billion. ${ }^{12}$

In 2019, an investment tribunal awarded a foreign mining company US\$ 6 billion in compensation against Pakistan, two months after the International Monetary Fund had agreed a US $\$ 6$ billion bailout with Pakistan to save its economy from collapse (Masood 2019). ${ }^{13}$ In effect, every ISDS award paid out by a losing state constitutes a cash transfer to private investors from the pool of public resources that ought to be invested in public collective goods. This requires diverting taxpayers' money away from funding for public health, access to food and employment creation among other public concerns.

Given that most IIAs do not require exhaustion of local remedies, nor organize the interaction between international arbitral tribunals and domestic courts where need be, such as when tribunals are dealing with or applying domestic laws, this regime has led to the marginalization of the role of domestic courts in international investment governance. ${ }^{14}$ Besides excluding national courts from the process of hearing disputes involving public law and public policy matters, the current regime and the systematic use of ISDS have allowed private investors to challenge the decisions of the highest courts in a sovereign country.

The current lack of a rule on exhaustion of local remedies in relation to investor-state disputes stands out in comparison to the usual practice under international law, where exhaustion of local remedies is of fundamental importance to the law of state international responsibility and the international procedural law of diplomatic protection (Douglas 2003: 240). Under these principles of diplomatic protection, a state can bring international proceedings based on the violation of the rights of one of its nationals only once the latter has exhausted any remedies available to it in the local courts of the opposing state. ${ }^{15}$ Even in human rights law, the rights holder who has allegedly suffered a violation must first turn

\footnotetext{
12 Calculation based on UNCTAD database for cases up to December 2018. Out of 310 disclosed cases which had been decided in favour of the investor or settled, information on damages was provided for $213(69 \%)$.

13 Tethyan Copper Company Pty Limited v. Islamic Republic of Pakistan, ICSID Case No. ARB/12/1

14 Aisbett et al. (2018: 115). This 2018 report by various international experts in foreign direct investment concluded that 'The ISDS system has led to the marginalization of domestic courts and legal institutions that can often be bypassed as a result of provisions in IIAs'.

15 Interhandel (Switzerland v. United States), Judgment of 21 Mar. 1959, [1959] ICJ Reports 27.
} 
to domestic authorities with his or her grievance, thus allowing them to correct any injustice that may have occurred, ${ }^{16}$ before proceeding to regional or international mechanisms. For all of those reasons, some countries have been revisiting their approach to the relationship between domestic and international dispute settlement forums. ${ }^{17}$

Overall, these rules provide international investors, which often operate through the legal structure of a multinational corporation, a leverage and disproportionate power to influence law and policy, in ways that could undermine the advancement towards sustainable development, democratic governance and the fulfillment of human rights (Johnson 2019).

\section{Focus on Quantity: The Unfounded Assumption that Investment Treaties Help Attract FDI}

IIAs were signed primarily based on the premise of attracting FDI. However, empirical evidence pertaining to a positive correlation between IIAs and FDI does not prove to be solid (Yackee 2011, UNCTAD 2014a). Authoritative research by academics and international institutions do not provide conclusive evidence about a positive correlation between signing up to these treaties and attracting FDI.

For example, an OECD study from 2018 that comprehensively reviews the existing evidence shows diverse and at times contradicting results. Some studies found a positive correlation, at least in certain configurations, some found a very weak, none, or even a negative correlation, and some studies found a correlation between IIAs and greater inflows, but not necessarily from the states with which a treaty has been concluded (Pohl 2018). Similarly, in 2014, the UNCTAD Trade and Development Report noted that 'results [of various studies in this field] do not support the hypothesis that BITs [bilateral investment agreement] foster bilateral FDI' (UNCTAD 2014b).

In 2010, an empirical study from the University of Oxford (Paulsen 2010) showed that it is exceedingly rare for foreign investors to factor in investment treaties when committing capital abroad, including deciding on the destination and volume of their investments. Similarly, availability and pricing of public and private political risk insurance is very

\footnotetext{
16 UNCITRAL Working Group III, Submission by South Africa, para 46, A/CN.9/WG.III/WP.176, http://undocs.org/en/A/CN.9/WG. III/WP.176.

17 This issue is on the agenda of discussions at UNCITRAL WGIII dealing with reform of investor-state dispute settlement. See: https:// uncitral.un.org/en/working_groups/3/investor-state. For example, India's new model investment treaty requires exhaustion of local remedies. New dispute settlement rules between the United States and Mexico under the United States-Mexico-Canada Agreement require exhaustion of local remedies.
}

rarely affected by the presence or absence of an IIA, including ISDS.

Moreover, numerous studies, including by the World Bank, indicate that IIAs are hardly the determining factor for investors when making the decision to invest. Other factors, such as market size and growth potential, a skilled workforce, availability of natural resources and adequate infrastructure appear to be more important determinants of FDI (Hornberger et al. 2011).

Furthermore, countries that have terminated their IIAs saw no decrease in their FDI inflow as a result. For example, when South Africa began terminating its IIAs after a cabinet review undertaken in 2009, it remained a top receiver of FDI on the African continent. In 2013, it was ranked by UNCTAD as the top recipient of FDI inflows among the African countries. When Bolivia started to systematically withdraw from its IIAs that reached expiration dates starting in 2006, leading to collectively denouncing all its remaining BITs in May 2013, it did not see FDI flows recoil. To the contrary, FDI inflows into Bolivia increased over that period, reaching an unprecedented peak of US\$ 1.75 billion in 2013. During the period when Brazil had not ratified any IIAs because they were not approved by its Congress due to their imbalance and impact on the state's right to regulate, Brazil was one of the largest receivers of FDI, and was ranked the fifth largest recipient of FDI in the world in 2013. ${ }^{18}$

Therefore, the main economic justification of investment treaties with the kind of privileges to foreign investors as described above is rarely fulfilled in practice.

\section{A Set of Rules that Treat all Investors Alike}

The set of rules laid out in IIAs often treat all investors the same irrespective of their impact on the host economy and on other developmental considerations of concern to the host country and its local communities. For example, the definition of investors and investments covered by such treaties is usually broad as a result of which treaty protections often extend to assets that may not have any economic benefit on the host economy, ${ }^{19}$ and in some cases could potentially cause harm.

Moreover, core non-discrimination standards of protection provided by these treaties, such as most-favored nation treatment and national treatment, restrict the ability of States to differentiate between investors, whether foreign or foreign and national, even when operating in different sectors with different economic and developmental implications.

\footnotetext{
18 Excluding the estimate for British Virgin Islands.

19 These include intangibles such as mortgages, intellectual property rights, shares, stocks and similar forms of participation in companies.
} 
By signing up to such treaties, States effectively give up the tools and loose the grounds based on which they could differentiate between an investor that does harm to the environment and natural resources and another that adds value to national economic and developmental objectives.

For those reasons, some countries have been trying to address this imbalance through revisiting the definition and scope of protected investments and investors under their IIAs in order to target protections towards those investments with developmental added value. ${ }^{20}$

\section{Stripping Away the Tools that States Need to Enhance Linkages Between Investment and Developmental Objectives}

It has been well-documented that the experience with investment treaties strongly suggests that policy interventions that would be necessary to contain adverse effects of FDI on stability, balance of payments, capital accumulation and industrial development and to activate its potential benefits, have been increasingly circumscribed through rules imbedded in international investment treaties (Akyüz 2015). Tools that historically have been actively used by today's industrialized countries to stimulate industrial development, have been circumscribed by these treaties (Mohamadieh and Montes 2015).

For example, certain investment treaties prohibit a number of performance measures, which are requirements that investors will have to fulfill for entry and operation in the host state, some of which are sometimes linked to certain incentives. Performance requirements could include local content and local processing requirements, requirements to establish joint ventures with domestic participation, requirements for a minimum level of domestic equity participation, employment requirements, research and development requirements, technology development, environmental assessment requirements, among others.

While foreign companies could contribute to facilitating host states' access to technologies, skills, and other development related added values, these gains are not automatic. Performance measures are tools that could induce investors to make these contributions as part of their operations (Mohamadieh and Montes 2015). Thus, treaty restrictions on performance requirements have the effect of reducing scenarios in which mutual benefit could accrue both to investors as well as the host state and local communities (International Institute for Sustainable Development 2012: 29).

\section{Disregarding the State's Broader Developmental and Human Rights Obligations}

While focusing on protections that states provide to investors, IIAs have not been designed in a way that takes account of the state's broader developmental and human rights obligations towards rights holders in its territory and jurisdiction. Besides being mute on such issues, IIAs, particularly the way they are interpreted and applied in ISDS cases, have undermined the capacity of the state to fulfill these obligations.

Among the human rights community, there is a clear recognition that states should actively address this tension. Multiple human rights authorities have addressed this issue. For example, the Committee on Economic, Social and Cultural Rights (CESDR) recognized that the negotiation and conclusion of trade and investment agreements could obstruct states from complying with their obligations under the International Covenant on Economic, Social and Cultural Rights. ${ }^{21}$ The UN Guiding Principles on Business and Human Rights have also addressed this interface. Guiding Principle 9 provides that 'States should maintain adequate domestic policy space to meet their human rights obligations when pursuing business-related policy objectives with other States or business enterprises, for instance through investment treaties or contracts'. 22

Human rights law and investment law remain generally alien to each other except in rare cases where there is reference to human rights in the treaty itself or human rights are brought up in an investment dispute by either

\footnotetext{
${ }^{21}$ General Comment 24 of the CESCR, para. 13.

22 The commentary on this principle explains that: '(...) the terms of international investment agreements may constrain States from fully implementing new human rights legislation, or put them at risk of binding international arbitration if they do so. Therefore, States should ensure that they retain adequate policy and regulatory ability to protect human rights under the terms of such agreements, while providing the necessary investor protection'. https://www.ohchr.org/ documents/publications/guidingprinciplesbusinesshr_en.pdf
}

\footnotetext{
${ }^{20}$ India's model investment treaty requires compliance of the investor with the law of the host country and fulfillment of a set of characteristics including 'commitment of capital or other resources, certain duration, the expectation of gain or profit, the assumption of risk and significance for the development of the party in whose territory the investment is made' (Article 1.4).
} 
the claimant investor, ${ }^{23}$ the defendant state $^{24}$ or third parties. $^{25}$

When arbitration tribunals found jurisdiction to address human rights, ${ }^{26}$ they have been reluctant to diagnose a real conflict between investment law and human rights. For example, in a case against Argentina concerning water related services, the arbitration tribunal argued that Argentina is subject to both international obligations, those under human rights law and the investment obligation, and must respect both of them equally. ${ }^{27}$ The tribunal opined that Argentina's human rights obligations and its investment treaty obligations are not inconsistent, contradictory or mutually exclusive, and thus Argentina could have respected both types of obligations.

In doing so, arbitration tribunals construct an argument to justify their decisions that states must pay large amounts of money as compensation to the investor even when the measures they took were non-discriminatory and in pursuit of fulfilling a human right.

\section{Undermining the Rights of Third Parties Impacted by Investments}

Third parties are often impacted by investors' practices, whether directly where their resources and livelihoods are touched, or indirectly through ISDS cases. In ISDS cases, investors can make allegations and raise issues that affect third parties, yet these parties usually do not have a legal right to participate, and no right to reply, even though they could be affected by the legal interpretations undertaken by the tribunal and/or remedy awarded.

Moreover, when third parties, including local communities, are adversely affected by investors' conduct, and their government seeks to address that through local state measures, such action could be challenged by investors through

\footnotetext{
${ }^{23}$ Hesham Talaat M. Al-Warraq v Republic of Indonesia, UNCITRAL, Final Award (15 December 2014), where the investor argued that human rights were included in the term 'basic rights' contained in the relevant BIT and Spyridon Roussalis v Romania, ICSID Case No ARB/06/1, Award (7 December 2011) where the claimant based its claim on, among other grounds, art 1 of the First Additional Protocol to the European Convention on Human Right. For more information on Hesham Talaat M. Al-Warraq v Republic of Indonesia (Cotula 2016).

${ }^{24}$ Suez and Vivendi v Argentina (30 July 2010) which relate to decision by Argentina to renegotiate tariff on private water supply and where Argentina referenced the fulfillment of the right to water.

${ }^{25}$ Bear Creek Mining Corporation v. Republic of Peru, ICSID Case No. ARB/14/21.

${ }^{26}$ Finding jurisdiction depends on the substantive content of the treaty and the way key provisions are crafted, such as provisions pertaining to applicable laws and counterclaims.

27 Suez and Vivendi v Argentina (30 July 2010).
}

ISDS. Investors could claim that those measures undermine the protections available to investors under international rules. If communities protest an investment and the state does not take measures against the communities in order to ensure the 'full security' of the investment, that could potentially trigger an ISDS case.

At the same time, rights holders face multiple challenges in seeking remedy and justice when they are subject to violations by investors, especially investors operating through a corporate structure that includes subsidiaries in host states and a parent company in the home state of the investor. These challenges include jurisdictional ones pertaining to accessing courts in the home state of the investor as well as other challenges pertaining to enforcement of judgements that might be decided in their interest.

Piercing the corporate veil and proving control over the actions that caused the harm has added to these challenges. While shareholder companies can directly initiate legal proceedings through ISDS to recover damages on behalf of their subsidiaries, these companies are usually protected by the corporate veil in case their subsidiaries engage in human rights violations against the local communities (Gaukrodger 2014).

\section{Re-envisioning Investment Governance to Balance and/or Reverse Investor Privileges}

\section{Reclaiming the State's Policy and Legal Tools}

The act of re-envisioning the investment governance regime, including balancing or reversing investor privileges where needed, is fundamentally intertwined with our understanding of the role and obligations of the state.

Effective advancement from a narrative linking investment to sustainable development towards real action requires a shift away from envisioning the role of the state to be mere facilitating and serving the market dynamics and private interests, including through the legal institutions it sets in place. Instead, it requires focusing the role of the state on creating an enabling environment for sustainable development that deploys positive action and cooperation by both states and investors, along with other actors including local communities and rights holders.

These shifts require preserving the policy and regulatory space of the state and reclaiming tools that have been restricted as a result of commitments taken under IIAs, in order to ensure that private interests do not undermine or supersede advancements in the service of the public interest. 


\section{Rethinking the Substantive and Procedural Aspects of International Investment Rules}

A rethinking of the investment governance regime, including balancing and/or reversing investor privileges and reclaiming State's policy and regulatory tools, requires a fundamental rethinking of the role and content of international investment agreements (IIAs). This entails rethinking both the substantive protection standards as well as the dispute settlement mechanisms under these treaties. Indeed, substantive and procedural provisions are intertwined in nature and inextricably linked. Whatever dispute settlement system is adopted, problems cannot be resolved as long as substantive law remains unreformed.

One starting point is the question of whether, and if so when, are IIAs needed in such a governance regime or if other legal frameworks, such as national laws, ought to be the core of such a regime. For example, South Africa set in place a Protection of Investment Law in 2015 after it terminated its IIAs. This in effect levels the playing field in the treatment of foreign and domestic investors.

Clarifying the scope of investments and investors that benefit from IIAs is crucial in a process of directing State action and legal commitments towards dynamically linking investment with sustainable development objectives. If the latter is the objective, then IIAs ought to be dedicated to facilitating investments by a certain category of investors, not all, particularly those who add value to the sustainable development trajectory while not doing harm. Some countries have commenced experimenting with redesigning the boundaries of the category of investments and investors covered under IIAs, although the sustainable development linkage is not fully explored yet.

Another aspect of this redesign ought to tackle the substantive protection standards that have proven to be problematic under IIAs. This includes those standards that are indeterminant and vague, such as 'fair and equitable treatment' and 'indirect expropriation', thus leaving ample space for being interpreted and applied in a manner that is intrusive on State's policy and regulatory space. Besides, IIAs ought to be reviewed with a view towards lifting restrictions, where they exist, on important policy and regulatory tools, such as performance requirements.

While recently reformed IIAs include language pertaining to the 'right to regulate', ${ }^{28}$ the efficacy of such language

\footnotetext{
${ }^{28}$ For example, Art. 8.9.1 of the Comprehensive Economic and Trade Agreement is a free-trade agreement between Canada and the European Union (CETA), the parties 'reaffirm their right to regulate within their territories to achieve legitimate policy objectives, such as the protection of public health, safety, the environment or public morals, social or consumer protection or the promotion and protection of cultural diversity'.
}

is doubted, especially as it often hides deep differences. The apparent consensus over the preservation of the right to regulate and the space for legitimate regulation in the public interest masks the potential for substantial disagreement, whereby developed countries are usually concerned with measures aimed to curb market abuse, while developing countries usually refer to development policy, including measures to increase local content or support national champions (Lang and Perrone 2017: 287).

Furthermore, one of the main shortcomings of including 'right to regulate' language is that it does not change the substantive rules of these agreements. It also usually does not add any legal obligations or rights and does not explicitly cover human rights obligations. It eventually serves as an interpretative tool but does not guarantee that the State's policy space and tools go unchallenged. While IIAs do not directly limit the 'right' of States to regulate, which is an essential feature of States' sovereignty, it does limit the policy options and choices of States on how to exercise the right to regulate, by excluding certain regulatory measures or putting them under pressure through requiring the State to pay compensation. The 'right to regulate' language does not change this.

When it comes to reforming investor-State dispute settlement (ISDS), the starting point ought to be whether, and in what cases, should investors be allowed to directly challenge the State. For example, should non-discriminatory measures taken by governments to fulfill their obligations under international treaties pertaining to a collective public good, such as addressing the climate crisis, public health objectives, or fulfilling human rights more broadly be subject to such challenges? ${ }^{29}$ Where ISDS is an option, should it be based on international arbitration and what should be the role of alternatives to arbitration, such as that of domestic courts? (Mohamadieh 2019c; Kelsey 2019.) For example, in United States-Mexico-Canada Agreement (USMCA or renegotiated NAFTA), ISDS was eliminated between the United States and Canada, while ISDS was limited to direct expropriation and discrimination between Mexico and the United States with a requirement to exhaust local remedies, except for specified claims.

The role of home states in regulating their nationals and holding them accountable where they do harm is an important part of building a cooperative international governance of investments and investors, founded on mutual assistance between investor home and host states. This could include

\footnotetext{
29 'Potential Solutions for Phase 3: Aligning the Objectives of UNICTRAL Working Group III with States' International Obligations to Combat Climate Change', Client Earth submission to WGIII, https:// uncitral.un.org/sites/uncitral.un.org/files/media-documents/uncitral/ en/wgiii_clientearth.pdf.
} 
clarifying the obligation of home states' courts to recognize foreign direct liability in situations where an investment by a national causes damages and harm in another state and taking relevant judicial action against the concerned investor. ${ }^{30}$ This is closely connected with the need to advance the domestic legal framework in home states of investors, in order to clarify their obligations when operating domestically as well as extra-territorially.

Such elements will be crucial in tackling a major asymmetry of international law that allows foreign investors special rights under IIAs but no liabilities. This is because they remain beyond the scope of host state courts, particularly where they operate in the host state through a separate domestic enterprise, and are also not subject to the jurisdiction of their home state courts for damages occurring outside its territory.

\section{Effective Recognition that not all Investors are the Same}

An element usually missing in investment treaties are investor obligations that both host and home states of investors except them to fulfill. While older general investment treaties generally did not address investor obligations, some new treaty practice is showing a different take on these issues. UNCTAD points out that one of the salient features of new IIAs is a balance between investor protections and investor obligations through the investor's duty to comply with host state domestic laws and regulations, abstain from corruption, uphold labour rights, undertake impact assessments and meet corporate social responsibility standards (UNCTAD 2019). However, this issue has not been given enough attention. Moreover, the approaches by states towards addressing these issues under their treaties vary from aspirational language to more direct clear obligations. ${ }^{31}$

\footnotetext{
30 This will aid in overcoming jurisdictional challenges arising from the doctrine of forum non conveniens, which allows courts the discretion to refuse cases even where they would have jurisdiction, based on the argument that other courts are more appropriate. SADC model BIT, https://www.iisd.org/itn/wp-content/uploads/2012/10/sadcmodel-bit-template-final.pdf.

31 For example, Brazil's investment agreement with Malawi provides a section on 'Corporate Social Responsibility', which requires that 'Investors and their investment shall strive to achieve the highest possible level of contribution to sustainable development and shall develop their best efforts to comply with following voluntary principles and standards for a responsible business conduct and consistent with the laws adopted by the Host Party including human rights'. The Nigeria-Morocco investment agreement (2016) imposes a number of human and social obligations on investors and incorporates an enforcement mechanism whereby the investor can be held civilly liable in its home state for damages caused in host state. Bilateral investment agreement between Morocco and Nigeria, Article15 on Investment, Labour and Human Rights Protection and Article 20 on Investor Liability, https://investmentpolicy.unctad.org/international-
}

Increasingly, there is recognition that not all investors and investments add value when it comes to sustainability objectives. This issue is evolving into the mainstream narrative. For example, OECD research on the qualities of FDI focuses on 'assessing the contribution of foreign investment to sustainable development and identifying policies to maximise positive impacts and minimise potential negative impacts' (Sauvant and Mann 2017; OECD 2019: 30). The research focuses on five qualities including productivity and innovation, employment and job quality, human capital and skills, gender equality and carbon footprint. Another OECD paper points out the "powerful convergence of thinking about both the respective roles of governments and business in addressing business conduct that generates adverse impacts, as well as on the content of business responsibilities' (Gaukrodger 2020).

The UN Guiding Principles, adopted by consensus at the level of the UN Human Rights Council, provides that businesses 'should avoid infringing on the human rights of others and should address adverse human rights impacts with which they are involved' (principle 11) including: 'avoid causing or contributing to adverse human rights impacts through their own activities, and address such impacts when they occur' and 'seek to prevent or mitigate adverse human rights impacts that are directly linked to their operations, products or services by their business relationships, even if they have not contributed to those impacts' (principle 12). ${ }^{32}$

If the investment governance regime is to be redesigned in a way that serves sustainable development and fulfillment of human rights, then IIAs ought to move beyond silence on the issues discussed above. This includes incorporating tools in IIAs to distinguish between investors who add value and those who do harm in their host environment, particularly when defining the subjective scope of IIAs, the obligations of covered investors, as well as the conditions for benefiting from any protections and privileges made possible by these treaties.

\section{Beyond International Investment Rules: Advancing National Legal Frameworks and Liability Regimes}

Essential to re-envisioning the investment governance regime is advancing the national legal frameworks through which investor obligations would be concretized and clarified, including, for example, human rights legal frameworks. This is a crucial complement to reforming IIAs, and involves

\footnotetext{
Footnote 31 (continued)

investment-agreements/treaties/bilateral-investment-treaties/3711/ morocco---nigeria-bit-2016-

32 https://www.ohchr.org/documents/publications/guidingprincipl esbusinesshr_en.pdf.
} 
the role of the home state in regulating its nationals when they operate abroad, what is known as domestic regulation with extraterritorial reach.

States have existing obligations under international human rights law (IHRL) to regulate the conduct of their businesses when operating in their territory or jurisdiction. ${ }^{33}$ UN Human Rights Treaty Bodies have recognized that states have positive obligations to "exercise due diligence to prevent, punish, investigate or redress the harm caused by private persons or entities'. ${ }^{34}$ In order to meet their duty of human rights due diligence, states should adopt effective measures to prevent future injury and respond to past injury in cases of violations in the context of business activities and operations, ${ }^{35}$ and have adequate legal and institutional frameworks to provide remedies. ${ }^{36}$

However, usually these obligations are not fully or effectively fulfilled and the regulations are not in place or are not well developed. So today, often neither the investor's home nor host states have such regulations in place. Setting in place these domestic legal frameworks, including clarifying human rights obligations of investors and business entities, is crucial especially if the protections and privileges offered to investors under international rules are at a certain point to be conditioned on compliance with domestic human rights law (Johnson 2019).

Some state practice is emerging regarding adoption of mandatory human rights due diligence for businesses. ${ }^{37}$ In 2017 France adopted a law on duty of vigilance ${ }^{38}$ which

\footnotetext{
33 The Committee on Economic, Social and Cultural Rights (CESCR) provided that states should take steps to "prevent human rights contraventions abroad by corporations which have their main offices in their jurisdiction, without infringing the sovereignty or diminishing the obligations of host states under the Covenant.' Source: Statement on the obligations of State parties regarding the corporate sector and economic, social and cultural rights (2011), para. 5, available at: https://digitallibrary.un.org/record/715883? $1 \mathrm{n}=\mathrm{en}$ ${ }^{34}$ UN Doc CCPR/C/21/Rev.1/Add. 13 (2004), para. 8.

35 Human Rights Committee, General Comment 35, UN Doc. CCPR/C/GC/35 (2014), para. 9; General Comment 27, UN Doc. CCPR/C/21/Rev.1/Add.9 (1999), para. 6; and, Committee on the Rights of the Child, General Comment 16, UN Doc. CRC/C/GC/16 (2013) p. 2.

${ }^{36}$ Committee on the Rights of the Child, General Comment 16, UN Doc. CRC/C/GC/16 (2013), para. 4.

37 During February 2021, the German government agreed on a draft law on mandatory human rights due diligence. More information available at: https://www.business-humanrights.org/en/latest-news/ germany-govt-agrees-on-national-mandatory-due-diligence-law/. The European Union Commission has undertaken a consultation on potential mandatory human rights due diligence legislation. More information available here: https://www.business-humanrights.org/en/ latest-news/proposal-for-an-eu-wide-mandatory-human-rights-duediligence-law/

38 French Law on Vigilance, Loi n 2017-399 du 17 Mars 2017 relative au devoir de vigilance des sociétiés mères et des enterprises donneuses d'ordre, https://www.legifrance.gouv.fr/eli/loi/2017/3/27/
}

sets a number of obligations on companies headquartered in France, including affiliates of a foreign company. The law applies to those companies with either more than 5,000 employees in France in direct or indirect subsidiaries, or those entities that have more than 10,000 employees in total in France and foreign direct and indirect subsidiaries. The obligations established under the law include requirements on companies to establish a diligence plan to respect human rights and fundamental freedoms, including health and safety of persons and the environment. The law also requires covered companies to effectively implement the plan, and to publish due diligence plans and implementation reports and include them in its annual reports.

To effectively operationalize the implementation of such normative frameworks, it is important to clarify international and national liability regimes that would be attached to these responsibilities. For example, civil, criminal and administrative liability regimes ought to be developed under national laws. These issues are addressed in discussions pertaining to a legally binding instrument to regulate, in international human rights law, the activities of transnational corporations and other business enterprises taking place under the auspices of the UN Human Rights Council. ${ }^{39}$

\section{Concluding Observations}

Re-envisioning the investment governance regime with a view to reversing unjustified privileges of investors and genuinely contributing to sustainable development requires revival and redirection in the roles of both home and host states of investors. Instead of focusing their policy and legal interventions on providing an enabling environment for investors, states ought to utilize their policy and regulatory tools to direct investment towards sustainable development objectives.

Unlike the period of the New International Economic Order in the 1970s, the issues pertaining to governing international investments and investors are no longer defined solely by North-South positioning. Today, many developing

\section{Footnote 38 (continued)}

2017-399/jo/texte. For other recent developments in European countries, see https://www.business-humanrights.org/en/national-movem ents-for-mandatory-human-rights-due-diligence-in-european-count ries.

${ }^{39}$ Resolution 26/9 of the Human Rights Council, 'Elaboration of an international legally binding instrument on transnational corporations and other business enterprises with respect to human rights', July 2014, http://ap.ohchr.org/documents/dpage_e.aspx?si=A/HRC/ RES/26/9 and the work of the open-ended intergovernmental working group on transnational corporations and other business enterprises with respect to human rights, https://www.ohchr.org/EN/HRBodies/ HRC/WGTransCorp/Pages/IGWGOnTNC.aspx. 
countries are hybrids of capital exporters and importers. They also are home to a class of international capitalists that are beneficiaries of the current system and the status quo. So, while bearing in mind the historical dimensions of the evolution of the current investment governance system, today's endeavor ought to focus on re-envisioning the dynamics between the state and capital, public and private interests, and the balance between rights of Sovereigns states, of rights holders and of asset holders. It also requires the cooperation of investor home and host states.

There are no quick fixes in these processes. Solutions require revision and action at national and international levels. Investor home and host states ought to develop their national legal framework to fulfill their obligations towards regulating their nationals when operating domestically or extra-territorially. They should also cooperate in reviewing and redesigning international investment agreements with a view towards reclaiming policy space and balancing the rights and obligations of investors. Withdrawing from treaties that cannot be corrected as such ought to remain an option in the process of re-envisioning and re-directing the objectives driving the investment governance regime. Such an endeavor requires integrating the perspectives and interests of states, investors as well as rights holders.

\section{References}

Aisbett, Emma, Bernali Choudhury, Olivier de Schutter, Frank Garcia, James Harrison, Song Hong, Lise Johnson, Mouhamadou Kane, Santiago Peña, Matthew Porterfield, Susan Sell, Stephen E. Shay, and Louis T. Wells. 2018. Rethinking International Investment Governance: Principles for the 21st Century, http://ccsi.colum bia.edu/files/2018/09/Rethinking-Investment-Governance-Septe mber-2018.pdf.

Akyüz, Yilmaz. 2015. Foreign Direct Investment, Investment Agreements and Economic Development: Myths and Realities, South Centre, https://www.globalpolicy.org/component/content/article/ 270-general/52815-foreign-direct-investment-investment-agree ments-and-economic-development-myths-and-realities.html.

Bernasconi-Osterwalder, Nathalie, Sarah Brewin, and Nyaguthii Maina. 2020. Protecting Against Investor-State Claims Amidst Covid-19: A Call to Action for Governments, April, https://www. iisd.org/library/investor-state-claims-amidst-covid-19.

Correa, Carlos, and Jorge E. Viñuales. 2016. Intellectual Property Rights as Protected Investments: How Open are the Gates? Journal of International Economic Law 19 (1): 91-120.

Cotula, Lorenzo. 2016. Human Rights and Investor Obligations in Investor-State Arbitration. The Journal of World Investment and Trade 17 (1): 148-157.

Douglas, Zachary. 2003. The Hybrid Foundations of Investment Treaty Arbitration. British Yearbook of International Law 74 (1): 151-289.

Gaukrodger, David. 2020. Business Responsibilities and Investment Treaties, January, OECD consultation, https://www.oecd.org/daf/ inv/investment-policy/Consultation-Paper-on-business-responsibi lities-and-investment-treaties.pdf.
Gaukrodger, David. 2014. Investment Treaties and Shareholder Claims for Reflective Loss: Insights from Advanced Systems of Corporate Law, OECD, http://www.oecd.org/investment/investment-policy/ WP-2014_02.pdf.

Gaukrodger, David and Kathryn Gordon. 2013. Investor-State Dispute Settlement: A Scoping Paper for the Investment Policy Community, OECD Working Papers on International Investment, 2012/03: 64, Referenced in UNCITRAL Doc. A/CN.9/WG.III/WP.142, p. 3. https://doi.org/10.1787/5k46b1r85j6f-en

Hornberger, Kusi, Joseph Battat, and Peter Kusek. 2011. How Much Does Investment Climate Matter? published as World Bank Group- View Point: Public Policy for the Private Sector, http:// siteresources.worldbank.org/FINANCIALSECTOR/Resources/ 327-Attracting-FDI.pdf.

International Institute for Sustainable Development. 2012. Investment treaties and why they matter for sustainable development, International Institute for Sustainable Development.

Johnson, Lise. 2019. IIAs and Investor (Mis) Conduct, http://ccsi. columbia.edu/2020/01/21/iias-and-investor-mis-conduct/.

Kelsey, Jane. 2019. UNCITRAL Working Group III: Promoting alternatives to investor- state arbitration as ISDS reform, International Institute for Sustainable Investment ITN, October.

Lang, Andrew and Nicolás M. Perrone. 2017. Experimenting with International Investment Law: Initiatives from the Global South. In Michelle Sanchez Raton and Fabio Morosini (eds.), Reconceptualizing International Investment Law from the Global South. Cambridge University Press.

Masood, Salman. 2019. Pakistan to accept $\$ 6$ billion bailout from I.M.F., 12 May, New York Times, https://www.nytimes.com/ 2019/05/12/world/asia/pakistan-imf-bailout.html.

Mohamadieh, Kinda. 2019a. Investment Facilitation: Another Plurilateral Initiative at the WTO, Third World Network, October, https://twn.my/title2/briefing_papers/No102.pdf.

Mohamadieh, Kinda. 2019b. Challenges of Investment Treaties on Policy Areas of Concern to Developing Countries, G-24 Working Paper, March, https://www.g24.org/wp-content/uploads/ 2019/03/Challenges_for_developing_countries_in_IIAs.pdf.

Mohamadieh, Kinda. 2019c. The Future of Investor-State Dispute Settlement Deliberated at UNCITRAL: Unveiling a Dichotomy between Reforming and Consolidating the Current Regime, South Centre, https://www.southcentre.int/wp-content/uploa ds/2019/03/IPB16_The-Future-of-ISDS-Deliberated-at-UNCIT RAL_EN.pdf.

Mohamadieh, Kinda and Daniel Uribe. 2016. Approaches to International Investment Protection: Divergent Approaches between the TPPA and Developing Countries' Model Investment Treaties, South Centre (June), https://www.southcentre.int/wp-conte nt/uploads/2016/06/RP68_Approaches-to-International-Inves tment-Protection_EN.pdf.

Mohamadieh, Kinda, and Manuel Montes. 2015. Throwing Away Industrial Development Tools: Investment Protection Treaties and Performance Requirements. In Investment Treaties: Views and Experiences from Developing Countries, 49-88. Geneva: South Centre.

OECD. 2019. FDI Qualities Indicators: Measuring the Sustainable Development Impacts of Investment, Paris.

Ogle, Vanessa. 2014. State Rights against Private Capital: The "New International Economic Order" and the Struggle over Aid, Trade, and Foreign Investment, 1962-1981. Humanity: An International Journal of Human Rights Humanitarianism, and Development 5 (2): 211-234 (Summer).

Olivet, Cecilia, Lucia Barcena, Bettina Müller, Luciana Ghiotto, and Sara Murawski. 2020. Pandemic Profiteers: How foreign investors could make billions from crisis measures, April, Transnational Institute, https://longreads.tni.org/pandemic-profiteers/. 
Poulsen, Lauge. 2010. The Importance of BITs for Foreign Direct Investment and Political Risk Insurance: Revisiting the Evidence. In Yearbook on International Investment Law \& Policy 2009/2010. New York: Oxford University Press.

Perrone, Nicolás M. 2020. The ISDS Reform Process: The missing development agenda, March, https://www.southcentre.int/inves tment-policy-brief-19-march-2020/.

Pohl, Joachim. 2018. Societal Benefits and Costs of International Investment Agreements, OECD, https://www.oecd-ilibrary. org/docserver/e5f85c3d-en.pdf?expires $=1587907609 \& \mathrm{id}=$ id $\&$ accname $=$ guest $\&$ checksum $=$ FF4EB01D644F9E4EAA1C 71804E7109F9.

Sauvant, Karl P. 2019. Five key considerations for the WTO investment-facilitation discussions, going forward, Columbia FDI Perspectives No. 243 January 14, http://ccsi.columbia.edu/files/ 2018/10/No-243-Sauvant-FINAL.pdf.

Sauvant, Karl P. 2015. The Negotiations of the United Nations Code of Conduct on Transnational Corporations. Experience and Lessons Learned, The Journal of World Investment and Trade 16: 11-87.

Sauvant, Karl and Howard Mann. 2017. Towards an Indicative List of FDI sustainability Characteristics. E15 Initiative, ICTSD and World Economic Forum.

Singh, Kavaljit and Burghard Ilge. 2016. Rethinking Bilateral Investment Treaties: Critical Issues and Policy Choices, https://www.
somo.nl/wp-content/uploads/2016/03/Rethinking-bilateral-inves tment-treaties.pdf

UNCTAD. 2019. Taking Stock of IIA Reform: Recent Developments, June, https://unctad.org/en/PublicationsLibrary/diaepcbinf 2019d5_en.pdf.

UNCTAD. 2014a. The Impact of International Investment Agreements on Foreign Direct Investment: An Overview of Empirical Studies 1998-2014, IIA Issues Note, September. http://investmentpolic yhub.unctad.org/Upload/Documents/unctad-web-diae-pcb-2014Sep\%2024.pdf.

UNCTAD. 2014b. UNCTAD Trade and Development Report 2014, Chapter VI, page 155, Available at: http://unctad.org/en/pages/ PublicationWebflyer.aspx?publicationid=981.

Van Harten, Gus. 2018. Leaders in the Expansive and Restrictive Interpretation of Investment Treaties: A Descriptive Study of ISDS Awards to 2010. European Journal of International Law 29 (2): 507-549.

Yackee, Jason W. 2011. Do Bilateral Investment Treaties Promote Foreign Direct Investment: Some Hints from Alternative Evidence. Virginia Journal of International Law 51 (2): 397 (2010-2011).

Publisher's Note Springer Nature remains neutral with regard to jurisdictional claims in published maps and institutional affiliations. 